\title{
Influence of Two Fertilizer Levels on Forage and Crude Protein Yields of Seven Tropical Grasses ${ }^{1}$
}

\author{
Jaime Vélez-Santiago and J. A. Arroyo-Aguilu ${ }^{2}$
}

\begin{abstract}
Two levels of a commercial fertilizer, analysis 15-5-10, (intermediate-2240 and high-4,480 kg/ha/year) were evaluated for green forage (GF), dry forage (DF), and crude protein (CP) yields and dry matter (DM) content of slenderstem digit (Digitaria pentzii), common Guinea (Panicum maximum), Makueni (Panicum maximum) Coastcross-1 Bermudagrass (Cynodon dactylon), Callie (Cynodon plectostachyus), Stargrass (Cynodon nlemfuensis var. nlemfuensis), and Carib (Eriochloa polystachya) grasses. Mean crude protein, phosphorus, potassium, calcium and magnesium contents at the intermediate and high levels, respectively, were $7.6,8.7,0.29,0.25,1.97,2.02,0.45,0.49$ and $0.23,0.24$. Grasses were cut 17 times at a 45 -day interval for 765 consecutive days. Mean DF yield for the seven grasses increased $29 \%$ as a result of the higher fertilizer level. Significant differences in GF and CP yields occurred among grasses at the two fertilizer levels. At the intermediate fertilizer level, DF yields ranged from 22,364 to $34,717 \mathrm{~kg} / \mathrm{ha}$ per year for Carib and Slender-stem digitgrass, respectively. At the high fertilizer level, the variation was from 31,188 to 43,126 $\mathrm{kg} / \mathrm{ha}$ per year for Carib and Makueni grasses, respectively. During the short cool days from October 15, 1977 to February 27, 1978, Slenderstem digit and Makueni grasses significantly outyielded $(P=.05)$ common Guinea, Star, and Carib grasses in total DF yields.
\end{abstract}

\section{INTRODUCTION}

Forage and crude protein (CP) yields of most tropical grasses are greatly reduced throughout Puerto Rico during the short cool days. Vicente-Chandler et al. (11) reported that dry forage (DF) yields are only about half as high during the winter months (from December through March) as during the rest of the year. Sotomayor-Rios et al. $(3,4)$ reported similar findings for different tropical grasses in the humid mountain region of Puerto Rico.

Dry forage (DF) yields increase during the period of short cool days if better yielding species are used. Vázquez (6) reported that during the cool period from January to February in the Lajas Valley of Puerto Rico, Para (Brachiaria mutica) ${ }^{3}$ grass outyielded common Guinea (Panicum maximum) grass by $1,951 \mathrm{~kg}$ of DF per ha. Vélez-Santiago et al. obtained significant differences among cultivars of Bermudagrass (Cynodon dactylon) (8) and Napier (Pennisetum purpureum) (7) in the humid region of Puerto Rico.

In Florida, the DF yields of Slenderstem digitgrass (Digitaria pentzii)

${ }^{1}$ Manuscript submitted to Editorial Board December 5, 1983.

${ }^{2}$ Associate Agronomist, Corozal Substation and Nutritionist, Animal Industry Department, Agricultural Experiment Station, Mayagüez Campus, University of Puerto Rico, Rio Piedras, P.R.

${ }^{3}$ Now classified as B. purpurascens (Raddi) Henr. 
exceeded by $35 \%$ those of common Pangola grass (Digitaria decumbens), although total annual GF yields were the same (2). Grof and Harding (1) reported that Panicum maximum PRPI 349676 significantly outyielded $(\mathrm{P}=.01)$ seven other Panicums during the cool season in North Queensland. Also in Queensland, Strickland (5) reported that the mean cool season yields of Paspalum nicorae exceeded those of Pangola grass by $150 \%$.

Another method of increasing DF yields during the period of short cool days in Puerto Rico is by applying more nitrogen $(9,10,11)$.

The present study was undertaken to evaluate the annual and winter season yield performances of seven tropical grasses. Green forage (GF), $\mathrm{DF}$, and $\mathrm{CP}$ yields were determined for each grass subjected to two fertilizer rates.

TABLE 1.-Identification of 7 forage grasses

\begin{tabular}{|c|c|c|c|}
\hline Species & USDA PI $^{1}$ & $\mathrm{PRPI}^{2}$ & Common name ${ }^{3}$ \\
\hline Digitaria pentzii & 300935 & 11537 & $\begin{array}{c}\text { Slenderstem } \\
\text { digitgrass }\end{array}$ \\
\hline Panicum maximum & - & Commercial & Common Guinea \\
\hline P. maximum ${ }^{4}$ & 349676 & 12917 & Makueni Guinea \\
\hline Cynodon sp. & 255455 & 11504 & $\begin{array}{c}\text { Coastcross-1 } \\
\text { bermuda }\end{array}$ \\
\hline C. plectostachyus & - & 13330 & Calliegrass \\
\hline $\begin{array}{l}\text { C. nlemfuensis var. } \\
\text { nlemfuensis }\end{array}$ & - & Commercial \#2341 & Stargrass \\
\hline Eriochloa polystachya & & Commercial & Caribgrass \\
\hline
\end{tabular}

${ }^{1}$ United States Department of Agriculture plant introduction number.

${ }^{2}$ University of Puerto Rico Agricultural Experiment Station plant introduction number.

${ }^{3}$ All this material except Common Guinea and Carib grasses was introduced through the S-9 (H-94) research project.

${ }^{4}$ Commonwealth plant introduction 37910 number from North Queensland.

\section{MATERIALS AND METHODS}

The experiment was conducted at the Corozal Research and Development Center, located in the humid region of Puerto Rico. The soil is a Corozal clay (Ultisol), with $0-2 \%$ slope. The soil was top-dressed with $2,240 \mathrm{~kg}$ of calcium carbonate at the time of planting and after the first year of experimentation to sustain soil $\mathrm{pH}$ at approximately 5.8 .

Table 1 shows identification of the seven grasses. Common Guinea and Star (Cynodon nlemfuensis var. nlemfuensis) were used as control grasses. The experimental layout was a split plot design with the grasses assigned to main-plots, replicated four times. Fertilizer levels 2,240 (intermediate) and 4,480 (high) kg/ha/yr, of a commercial 15-5-10 analysis were applied to sub-plots. Main-plots were $27.88 \mathrm{~m}^{2}$, and sub-plots 
$13.94 \mathrm{~m}^{2}$. An alley of $0.92 \mathrm{~m}$ wide was left between main plots, and 0.31 $\mathrm{m}$ wide between sub-plots.

All grasses were harvested at a 45-day interval. Guinea grass plots were harvested at approximately $23 \mathrm{~cm}$ above the ground, the rest of the grasses at $8 \mathrm{~cm}$. At each cutting, GF was weighed, sampled, dried at $55^{\circ}$ $\mathrm{C}$ in a forced air oven, and ground in a Wiley mill to pass through a 1mm screen.

DM was determined for all samples. At each of the 17 cuttings, samples were composited over replications and each treatment was analyzed for $\mathrm{N}, \mathrm{P}, \mathrm{K}, \mathrm{Ca}$, and $\mathrm{Mg}$. CP content was computed as $\mathrm{N} \times 6.25$.

The data for the 17 cuttings were statistically analyzed for GF, DF, and CP yields and DM content, following the analyses of variance in Duncan's multiple range test. To evaluate the yield performance of the grasses during the period of short cool days, the three harvests from October 15, 1977 to February 27, 1978 were also analyzed as a group.

During the first and second year, rainfall totaled 1,630 and $1,610 \mathrm{~mm}$, respectively. During the 765-day period, the grasses received 11 sprinkle irrigations, or approximately $280 \mathrm{~mm}$ of additional moisture.

\section{RESULTS AND DISCUSSION}

Table 2 and figure 1 show the mean GF, DF, and CP yields of the seven grasses on the basis of 17 cuttings over a period of 765 days. At the intermediate fertilizer level, GF yields for Slenderstem digit, common Guinea, and Makueni (Panicum maximum PRPI 12917) were significantly higher than for the remaining grasses. At both fertilizer levels, the DM content was generally higher in Coastcross-1 (Cynodon dactylon) (PRPI 11504), Callie (Cynodon plectostachyus PRPI 13330), and Star grass than in the other species. In all grasses the DM content was highest at the intermediate fertilizer level.

At the intermediate fertilizer level, Slenderstem digit yielded more DF than Callie, Star, and Carib (Eriochloa polystachya) grasses. At the high fertilizer level, the Makueni cultivar significantly outyielded Coastcross1, Star, and Carib grasses.

At the intermediate fertilizer level, Slenderstem digit CP yields were higher than those of Makueni, Callie, Star, and Carib grasses, whereas at the high fertilizer level, Slenderstem outyielded Carib grass only.

Table 3 and figure 2 show the GF and DF yields and the DM content for the three cuttings during the short cool days of the year. Slenderstem digit, common Guinea, Makueni, and Carib grasses were the highest GF yielders; Coastcross-1, Callie, and Star grasses were the lowest yielders. Coastcross- 1 and Callie grasses had the highest DM content; Carib and common Guinea grasses had the lowest. Slenderstem digit DF yields 
TABLE 2.-Mean yield of green and dry forage and crude protein and contents of dry matter of seven tropical grasses fertilized at two levels and cut every 45 days during a period of 765 days at Corozal, Puerto Rico

\begin{tabular}{|c|c|c|c|c|c|c|c|c|}
\hline \multirow[b]{2}{*}{ Common name } & \multicolumn{4}{|c|}{ Intermediate fertilizer level } & \multicolumn{4}{|c|}{ High fertilizer level } \\
\hline & $\begin{array}{c}\text { Green } \\
\text { forage } \\
\text { yield }\end{array}$ & $\begin{array}{c}\text { Dry } \\
\text { matter } \\
\text { content }\end{array}$ & $\begin{array}{l}\text { Dry } \\
\text { forage } \\
\text { yield }\end{array}$ & $\begin{array}{l}\text { Crude } \\
\text { protein } \\
\text { yield }\end{array}$ & $\begin{array}{c}\text { Green } \\
\text { forage } \\
\text { yield }\end{array}$ & $\begin{array}{c}\text { Dry } \\
\text { matter } \\
\text { content }\end{array}$ & $\begin{array}{l}\text { Dry } \\
\text { forage } \\
\text { yield }\end{array}$ & $\begin{array}{l}\text { Crude } \\
\text { protein } \\
\text { yield }\end{array}$ \\
\hline & $\mathrm{kg} / \mathrm{ha} / \mathrm{yr}$ & $\%$ & $\mathrm{~kg} / \mathrm{ha} y \mathrm{r}$ & $\mathrm{kg} / \mathrm{ha} / \mathrm{yr}$ & $\mathrm{kg} / \mathrm{ha} / \mathrm{yr}$ & $\%$ & $\mathrm{~kg} / \mathrm{ha} / \mathrm{yr}$ & $\mathrm{kg} / \mathrm{ha} / \mathrm{yr}$ \\
\hline Slenderstem digitgrass & $133,949 \mathrm{a}^{1}$ & $26.33 \mathrm{c}$ & $34,717 \mathrm{a}$ & 3,393 a & $162,551 \mathrm{ab}$ & $24.13 \mathrm{c}$ & $38,474 \mathrm{ab}$ & 4,371 a \\
\hline Common Guinea & $136,389 \mathrm{a}$ & $23.71 \mathrm{~b}$ & $32,082 \mathrm{ab}$ & $2,886 \mathrm{ab}$ & $186,769 \mathrm{a}$ & $22.24 \mathrm{~d}$ & $40,589 \mathrm{ab}$ & $4,086 \mathrm{a}$ \\
\hline Makueni Guinea & 130,867 a & $24.85 \mathrm{~cd}$ & $32,066 \mathrm{ab}$ & $2,570 \mathrm{bc}$ & $185,118 \mathrm{a}$ & $23.75 \mathrm{~cd}$ & 43,126 a & $3,830 \mathrm{ab}$ \\
\hline Coastcross- 1 bermuda & $90,115 \mathrm{~b}$ & $32.10 \mathrm{ab}$ & $28,244 \mathrm{abc}$ & $2,810 a b$ & $124,515 \mathrm{~cd}$ & $29.76 \mathrm{~b}$ & $35,726 \mathrm{bc}$ & 4,122 a \\
\hline Calliegrass & 81,487 b & $33.23 \mathrm{a}$ & $26,813 \mathrm{bc}$ & $2,554 \mathrm{bc}$ & $129,045 \mathrm{~cd}$ & $31.46 \mathrm{a}$ & $39,369 \mathrm{ab}$ & 4,020 a \\
\hline Stargrass & 84,878 b & $30.60 \mathrm{~b}$ & $25,267 \mathrm{c}$ & $2,571 \mathrm{bc}$ & $111,821 \mathrm{~d}$ & $28.84 \mathrm{~b}$ & $31,716 \mathrm{c}$ & $3,634 \mathrm{ab}$ \\
\hline Caribgrass & $94,027 \mathrm{~b}$ & $24.40 \mathrm{~d}$ & $22,364 \mathrm{c}$ & $2,084 \mathrm{c}$ & $144,668 \mathrm{bc}$ & $22.11 \mathrm{~d}$ & $31,188 \mathrm{c}$ & $3,160 \mathrm{~b}$ \\
\hline$\overline{\mathrm{X}}$ & 107,387 & 27.87 & 28,793 & 2,695 & 149,212 & 26.04 & 37,170 & 3,889 \\
\hline
\end{tabular}

${ }^{1}$ Means in the same column followed by one or more letters in common do not differ significantly at the $5 \%$ probability level. 


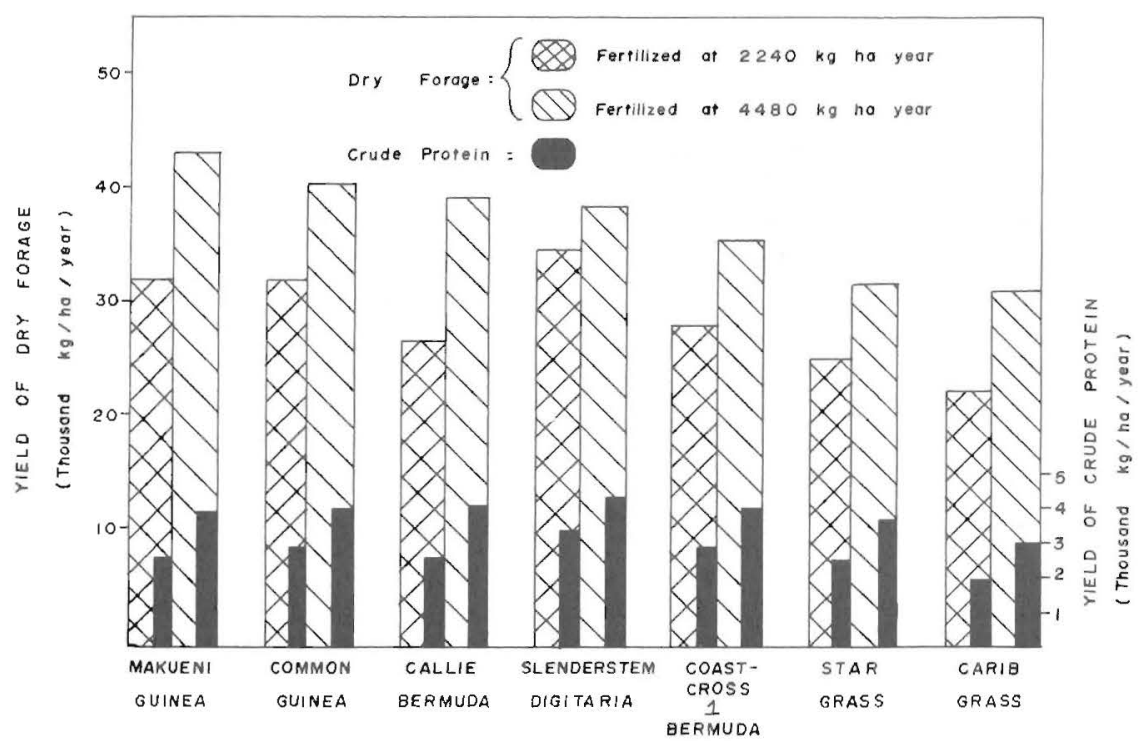

FIG. 1.-Effect of two fertilization rates on the yield of forage and crude protein of seven tropical grasses at Corozal, Puerto Rico.

TABLE 3.-Yields and dry matter content of seven tropical grasses fertilized at two levels and cut every 45 days from October 15, 1977, to February 27, 1978

\begin{tabular}{lcccc}
\hline \multicolumn{1}{c}{ Common name } & $\begin{array}{c}\text { Green } \\
\text { forage } \\
\text { yield }\end{array}$ & $\begin{array}{c}\text { Dry } \\
\text { matter } \\
\text { content }\end{array}$ & $\begin{array}{c}\text { Dry } \\
\text { forage } \\
\text { yield }\end{array}$ & $\begin{array}{c}\text { Crude } \\
\text { protein } \\
\text { yield }\end{array}$ \\
\hline Slenderstem digitgiass & $\begin{array}{c}\mathrm{kg} / \mathrm{ha} \\
48,867 \mathrm{a}^{1}\end{array}$ & $\begin{array}{c}\% \\
22.53 \mathrm{~cd}\end{array}$ & $\begin{array}{c}\mathrm{kg} / \mathrm{ha} \\
10,873 \mathrm{a}\end{array}$ & $\mathrm{kg} / \mathrm{ha}$ \\
Calliegrass & $35,070 \mathrm{bc}$ & $28.09 \mathrm{a}$ & $9,758 \mathrm{ab}$ & $785 \mathrm{bc}$ \\
Makueni Guinea & $44,809 \mathrm{a}$ & $23.89 \mathrm{bc}$ & $10,658 \mathrm{ab}$ & $735 \mathrm{bc}$ \\
Coastcross-1 bermuda & $35,023 \mathrm{bc}$ & $27.71 \mathrm{a}$ & $9,651 \mathrm{ab}$ & $845 \mathrm{ab}$ \\
Common Guinea & $41,530 \mathrm{ab}$ & $21.93 \mathrm{~cd}$ & $9,056 \mathrm{bc}$ & $707 \mathrm{bc}$ \\
Caribgrass & $43,946 \mathrm{a}$ & $20.78 \mathrm{~d}$ & $9,028 \mathrm{bc}$ & $717 \mathrm{bc}$ \\
Stargrass & $30,224 \mathrm{c}$ & $25.18 \mathrm{~b}$ & $7,560 \mathrm{c}$ & $666 \mathrm{bc}$ \\
\hline
\end{tabular}

${ }^{1}$ Means in the same column followed by one or more letters in common do not differ significantly at the $5 \%$ probability level.

significantly surpassed those of common Guinea, Star, and Carib grasses during the short cool days. The superiority of Slenderstem digit and of Makueni grasses over other grasses during the cool season were reported by McCaleb (2) in Florida and Grof and Harding (1) in North Queensland. In this study, both grasses, besides being the best yielders during the period of short cool days, were also the best for the entire year.

Table 4 shows the mean $\mathrm{N}, \mathrm{P}, \mathrm{K}, \mathrm{Ca}$, and $\mathrm{Mg}$ contents for the seven grasses at the two fertilizer levels. Mean $\mathrm{N}$ content was $12 \%$ higher at 


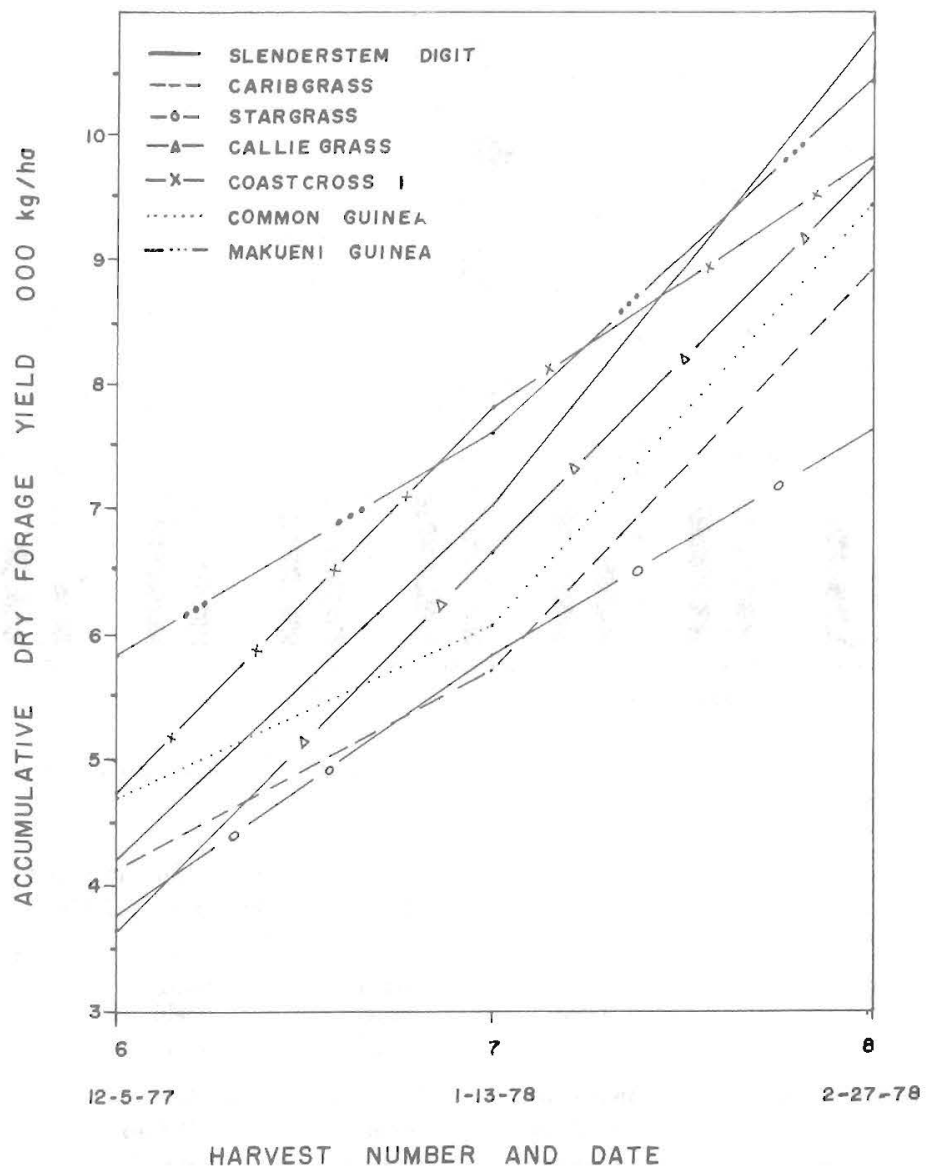

FiG. 2.-Cumulative dry forage production of seven tropical grasses from October 15, 1977, to February 27, 1978. Means of two fertilizer levels at Corozal, Puerto Rico.

the upper fertilizer level. Mean $\mathrm{P}$ contents did not increase, but mean $\mathrm{K}$, $\mathrm{Ca}$, and $\mathrm{Mg}$ contents increased slightly at the upper fertilizer level. Previous research in Puerto Rico $(7,10)$ demonstrated a similar trend in mineral content with an increase in fertilizer level.

\section{RESUMEN}

Los rendimientos anuales y estacionales de forraje verde (GF), forraje seco (DF) y proteína bruta (CP) se determinaron en siete gramíneas que se abonaron con 2,240 y $4,480 \mathrm{~kg}$ de un abono $15-5-10$ por ha y año durante 765 días consecutivos.

Según aumentó el nivel de abono aumentó la producción de GF, DF y $\mathrm{CP}$ en todas las gramíneas. Las mejores productoras de GF en el nivel 
intermedio de abono fueron las pangola de tallo fino, guinea común y Makueni. Las Bermuda Coastcross-1 y Callie fueron las más ricas en materia seca (DM) al nivel intermedio de abono; sin embargo, la. Callie superó en DM a las demás en el nivel alto de abono. Las mejores productoras de DF en el nivel intermedio de abono fueron pangola de tallo fino, guinea común, Makueni y Bermuda Coastcross-1. En la dosis intermedia de abono, la mejor productora de CP fue la pangola de tallo fino, que sobrepasó significativamente a las yerbas Makueni, Callie, estrella y malojilla.

Las mejores productoras de GF en la dosis intermedia de abono por lo general resultaron buenas productoras en la dosis alta. La gramínea Makueni fue la mejor productora de DF en la dosis alta de abono y superó significativamente a las yerbas Bermuda Coastcross-1, estrella y malojilla. Las gramíneas pangola de tallo fino, guinea común, Bermuda Coastcross-

TABLE 4.-Effect of two fertilizer levels on the mineral composition of seven tropical grasses harvested every 45 days

\begin{tabular}{|c|c|c|c|c|c|c|c|c|c|c|}
\hline \multirow{2}{*}{ Common name } & \multicolumn{5}{|c|}{ Intermediate fertilizer level } & \multicolumn{5}{|c|}{ High fertilizer level } \\
\hline & $\mathrm{N}$ & $\mathrm{P}$ & $\mathrm{K}$ & $\mathrm{Ca}$ & $\mathrm{Mg}$ & $\mathrm{N}$ & $\mathbf{P}$ & $\mathrm{K}$ & $\mathrm{Ca}$ & $\mathrm{Mg}$ \\
\hline & \multicolumn{10}{|c|}{$\%$} \\
\hline Slenderstem digitgrass & $1.27^{1}$ & .27 & 1.92 & .33 & .28 & 1.48 & .27 & 1.97 & .36 & .30 \\
\hline Common Guinea & 1.17 & .31 & 2.21 & .73 & .26 & 1.31 & .29 & 2.26 & .82 & .28 \\
\hline Makueni Guinea & 1.04 & .27 & 2.09 & .73 & .29 & 1.16 & .27 & 2.07 & .79 & .31 \\
\hline Coastcross-1 Bermuda & 1.29 & .29 & 1.69 & .28 & .16 & 1.50 & .27 & 1.84 & .28 & .16 \\
\hline Calliegrass & 1.24 & .29 & 1.74 & .39 & .17 & 1.33 & .29 & 1.79 & .43 & .18 \\
\hline Stargrass & 1.33 & .32 & 2.03 & .41 & .21 & 1.49 & .31 & 2.06 & .42 & .22 \\
\hline Caribgrass & 1.21 & .27 & 2.13 & .29 & .21 & 1.32 & .29 & 2.17 & .34 & .23 \\
\hline $\bar{X}$ & 1.22 & .29 & 1.97 & .45 & .23 & 1.37 & .25 & 2.02 & .49 & .24 \\
\hline
\end{tabular}

${ }^{1}$ Mean of 4 replicates.

1 y Callie superaron en producción de CP a la malojilla en la dosis alta de abono.

La pangola de tallo fino sobrepasó significativamente en producción de DF total a las yerbas guinea común, estrella y malojilla en tres cortes desde el 15 de octubre de 1977 al 27 de febrero de 1978. En adición, se presentan valores del contenido en nitrógeno, fósforo, potasio, calcio y magnesio de las siete yerbas en los dos niveles de abonamiento.

\section{LITERATURE CITED}

1. Grof, B. and Harding, W. A. T., 1970. Dry matter yields and animal production of Guinea grass (Panicum maximum) on the humid tropical coast of North Queensland, Trop. Grass1. 4 (1): 85-95.

2. McCaleb, J. E. and Hodges, E. M., 1969. Slenderstem Digitgrass, Univ. Fla. Agric. Exp. Stn. Circ. S-201.

3. Sotomayor-Ríos, A., Vélez-Fortuño, J., and Spain, G., 1971. Forage yields and plant 
character correlations in 30 Digitataria selections, J. Agric. Univ. P.R. 55 (1): 53-62.

4. —_ Vélez-Santiago, J., Torres-Rivera, S. and Silva, S., 1976. Effect of three harvest intervals on yield and composition of nineteen forage grasses in the humid mountain region of Puerto Rico, J. Agric. Univ. P.R. 60 (3): 294-309.

5. Strickland, R. W., 1978. The cool season production of some introduced grasses in south-east Queensland, Trop. Grassl. 12 (2): 109-12.

6. Vázquez, R., 1965. Effects of irrigation and nitrogen levels on the yields of Guinea grass, Para grass, Guinea grass-Kudzú and Para grass-Kudzú mixtures in Lajas Valley, J. Agric. Univ. P.R. 49 (4): 389-4.12.

7. Vélez-Santiago, J. and Arroyo-Aguilú, J. A., 1981. Effect of three harvest intervals on yield and nutritive value of seven Napier grass cultivars. J. Agric. Univ. P.R. 65 (2): 129-37.

8. —_ Sotomayor-Rios, A. and Torres-Rivera, S., 1979. Effects of three harvest intervals and two fertilizer rates on the yield and HCN content of ten Cynodon cultivars. J. Agric. Univ. P.R. 63 (1): 35-44.

9. Vicente-Chandler, J., Silva, S., and Figarella, J., 1959. The effect of nitrogen fertilization and frequency of cutting on the yield and composition of three tropical grasses, Agron. J. 51 (4): 202-6.

10. ——, Abruña, F. and Rodriguez, J. A., 1972. Effect of two cutting heights, four harvest intervals and five nitrogen rates on yield and composition of Congo grass under humid tropical conditions, J. Agric. Univ. P.R. 56 (3): 280-91.

11. _ـ Abruña, F., Caro-Costas, R., Figarella, J., Silva, S. and Pearson, R. W., 1974. Intensive grassland management in the humid tropics of Puerto Rico, Agric. Exp. Stn., Univ. P.R., Bull. 233. 